\title{
A real-time PCR genotyping assay to detect FAD2A SNPs in peanuts (Arachis hypogaea L.)
}

\author{
Noelle A. Barkley ${ }^{1} \cdot$ Ming Li Wang $^{1} \triangle \cdot$ Roy N. Pittman $^{1}$ \\ 1 USDA-ARS, Plant Genetic Resources Conservation Unit, 1109 Experiment Street, Griffin, GA 30223 USA
}

$\triangle$ Corresponding author: MingLi.Wang@ars.usda.gov

Received August 24, 2010 / Accepted December 13, 2010

Published online: January 15, 2011

(C) 2011 by Pontificia Universidad Católica de Valparaíso, Chile

\begin{abstract}
The high oleic (C18:1) phenotype in peanuts has been previously demonstrated to result from a homozygous recessive genotype $\left(\mathrm{Ol}_{1} \mathrm{Ol}_{1} \mathrm{Ol}_{2} \mathrm{Ol}_{2}\right)$ in two homeologous fatty acid desaturase genes ( $F A D 2 A$ and $F A D 2 B$ ) with two key SNPs. These mutant SNPs, specifically G448A in FAD2A and 442ins $A$ in $F A D 2 B$, significantly limit the normal function of the desaturase enzyme activity which converts oleic acid into linoleic acid by the addition of a second double bond in the hydrocarbon chain. Previously, a genotyping assay was developed to detect wild type and mutant alleles in FAD2B. A realtime PCR assay has now been developed to detect wild type and mutant alleles (G448A) in FAD2A using either seed or leaf tissue. This assay was demonstrated to be applicable for the detection of homozygous and heterozygous samples. The FAD2A genotyping assay was validated by employing gas chromatography (GC) to determine total fatty acid composition and by genotyping peanut lines that have been well characterized. Overall, development of rapid assays such as real-time PCR which can identify key genotypes associated with important agronomic traits such as oleic acid, will improve breeding efficiency by targeting desirable genotypes at early stages of development.
\end{abstract}

Keywords: fatty acid composition, gas chromatography, peanut (Arachis hypogaea L.), real-time PCR, SNP genotyping

\section{INTRODUCTION}

Cultivated peanuts (Arachis hypogaea L.) are allotetraploids $(2 n=4 x=40, \mathrm{AABB})$ and are grown worldwide in temperate and tropic zones (Norden et al. 1987). Oilseed crops, such as soybean, canola, sunflower, and peanut contribute to the majority of total oil production worldwide (López et al. 2002). Thus, cultivated peanuts are vital oilseed crops since their seeds are known to typically contain $45-51 \%$ oil (López et al. 2000). The majority of the oil extracted from peanuts are comprised of three predominant fatty acids, a saturated fatty acid, a monounsaturated omega-9 fatty acid, a polyunsaturated omega- 6 fatty acid, known as, palmitic (C16:0), oleic (C18:1), and linoleic (C18:2), respectively. However, including these three major fatty acids up to 12 fatty acids have been identified in peanuts (Norden et al. 1987; Dean et al. 2009).

The quality, flavour, and oxidative stability of peanut seeds or extracted oil are dependent on the fatty acid composition (López et al. 2000; Andersen and Gorbet, 2002). Achieving long-term oxidative stability of seed oils through alterations in fatty acid composition could make the common process of catalytic hydrogenation of vegetable oils unnecessary (Chu et al. 2007b). Rancidity is most prevalent among oils with high levels of polyunsaturated fats (Moore and Knauft, 1989). Oleic acid is a highly stable fatty acid compared to linoleic acid; therefore, high oleic to linoleic ratios (high O/L) are generally preferred. Thus, due to the increased shelf life of high oleic peanuts along with the associated nutritional benefits of consuming high oleic products, such as slowing down atherosclerosis (Yu et al. 2008) and reducing LDL cholesterol levels (O'Byrne et al. 1997), make high oleic products a valuable commodity. 


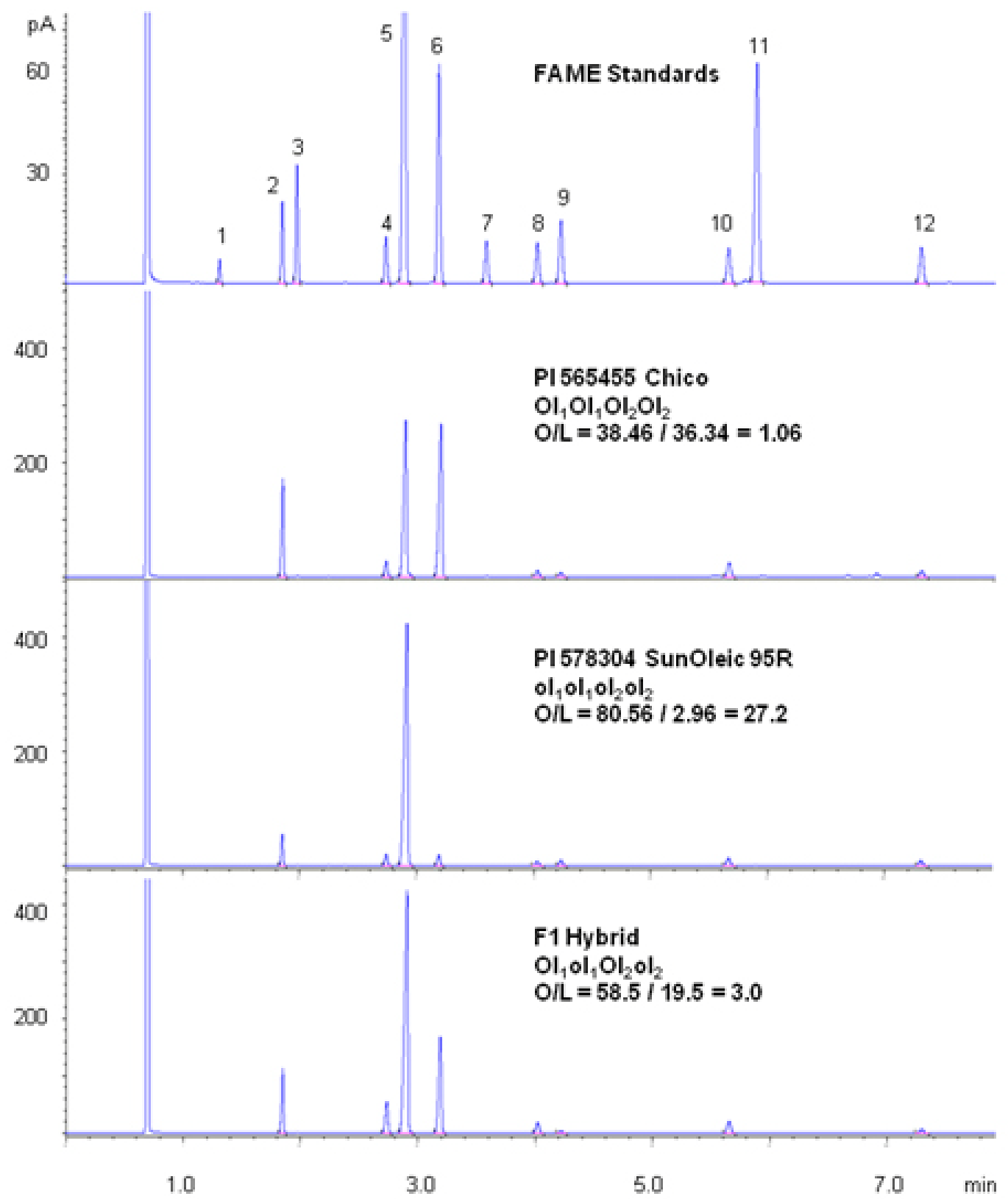

Standards: $1=14: 0,2=16: 0,3=16: 1,4=18: 0,5=18: 1$ (oleic), $6=18: 2$ (linoleic). $7=18: 3,8=20: 0,9=20: 1,10=22: 0,11=22: 1,12=24: 0$ 

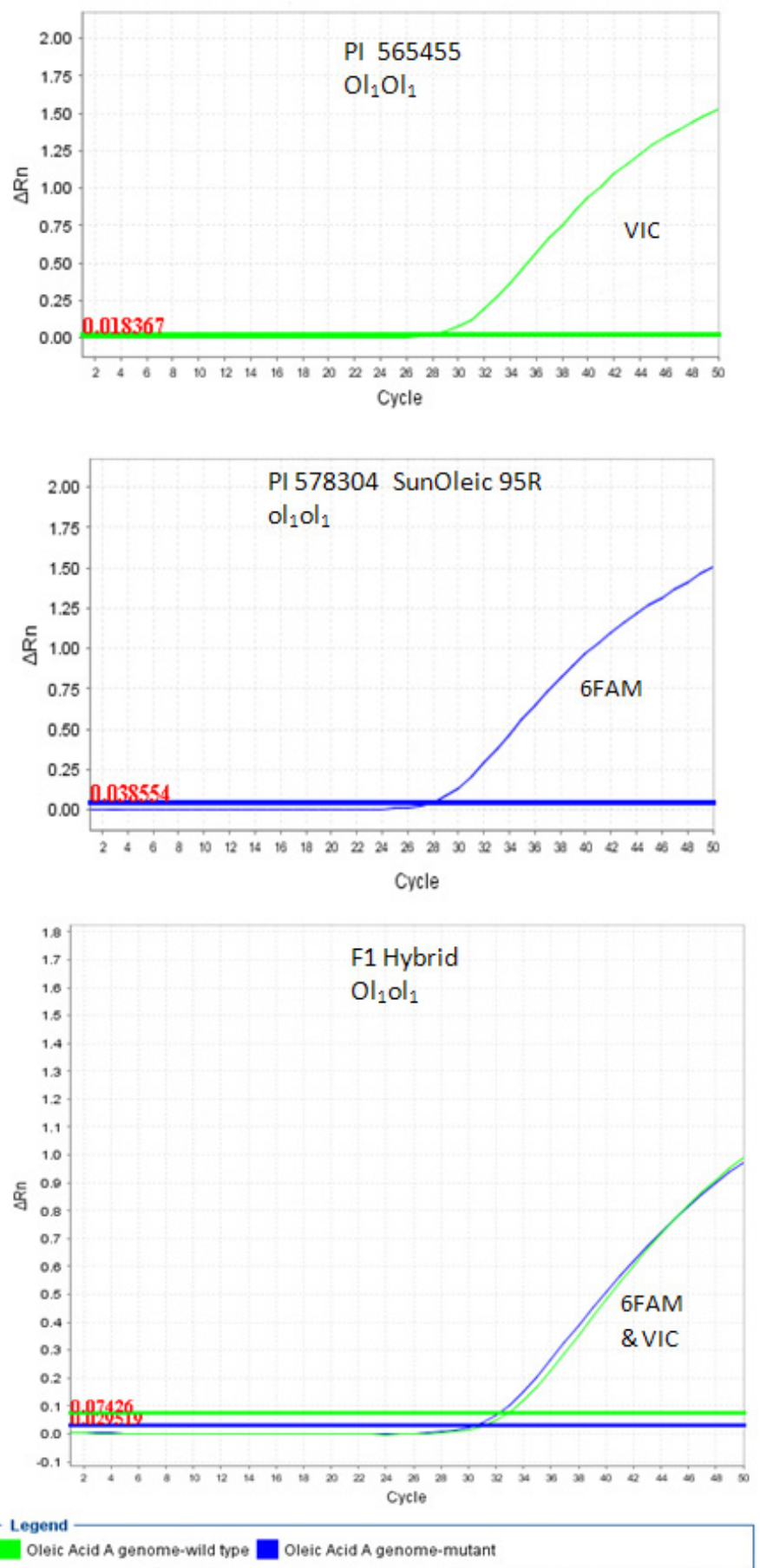

Fig. 1 (a) Chromatogram showing the fatty acid composition of three different ol genotypes $\left(\mathrm{Ol}_{1} \mathrm{Ol}_{1} \mathrm{Ol}_{2} \mathrm{Ol}_{2}\right.$, $\mathrm{Ol}_{1} \mathrm{Ol}_{1} \mathrm{Ol}_{2} \mathrm{Ol}_{2}$, and $\mathrm{Ol}_{1} \mathrm{Ol}_{1} \mathrm{Ol}_{2} \mathrm{Ol}_{2}$,). The x-axis represents the retention time. Eight fatty acids were revealed for each sample; however, palmitic (C16:0), oleic (C18:1), and linoleic (C18:2) were the predominant fatty acids detected in these samples. (b) Amplification plots of the three FAD2A genotypes $\left(\mathrm{Ol}_{1} \mathrm{Ol}_{1}\right.$, $\mathrm{Ol}_{1} \mathrm{Ol}_{1}$, and $\left.\mathrm{Ol}_{1} \mathrm{Ol}_{1}\right)$ detected with real-time PCR using two TaqMan ${ }^{\circledR}$ probes to target the wild type and mutant allele (G448A) in FAD2A. The first amplification plot shows the homozygous dominant genotype, the middle plot is homozygous recessive, and the bottom plot is heterozygous. The $x$-axis represents the cycle number; whereas, the $y$-axis represents the normalized fluorescence. 
Due to the efforts of the Florida breeding program, the first high oleic line F435, was identified with $80 \%$ oleic and $2 \%$ linoleic, which was similar to the oleic acid level found in olive oil (Norden et al. 1987). Research since this discovery has revealed that the high oleic trait segregates in a digenic (15:1) or monogenic (3:1) fashion dependent on the parental genotypes (Moore and Knauft, 1989; Jung et al. 2000b; López et al. 2001). The high oleic phenotype was demonstrated to be a consequence of decreased enzyme activity with mutants having $<10 \%$ activity (Ray et al. 1993). Subsequent characterization of the homoeologous fatty acid desaturase genes (FAD2) revealed a high degree $(99 \%)$ of identity (Jung et al. 2000 a) with few polymorphic SNPs among normal and high oleic lines. A missense mutation (G448A, D150N) was uncovered in FAD2A between high and normal oleic peanuts (López et al. 2000). Further, high oleic lines had a single base pair insertion (442insA) in FAD2B producing a frame shift and several downstream stop codons (López et al. 2000). Both of these mutations (G448A and 442insA) are necessary to produce a high oleic phenotype (Jung et al. 2000b).

Elite high oleic cultivars are needed to thwart disease and abiotic challenges that exists in different environments. However, development of cultivars with enhanced traits can be a time-consuming process. Marker assisted selection (MAS) can expedite the breeding process by allowing desired genotypes to be selected at an early stage. Cleaved amplified polymorphic sequence (CAPS) markers have been developed for FAD2A (Chu et al. 2007b) and FAD2B (Chu et al. 2009) along with an allelespecific PCR (AS-PCR) method (Chen et al. 2010). Also, a real-time PCR genotyping assay was developed to discriminate wild type and mutant alleles in FAD2B (Barkley et al. 2010). These various markers for $F A D 2 A$ and $F A D 2 B$ will allow breeders and researchers to determine genotypes of peanut lines by multiple means dependent on their available laboratory resources. Therefore, the goal of this work was to develop a real-time PCR genotyping assay to rapidly assess the wild type and mutant alleles in $F A D 2 A$, determine the fatty acid composition for each sample by $G C$, and validate the assay by genotyping peanut accessions previously characterized for FAD2A.

\section{MATERIALS AND METHODS}

\section{Plant material}

All plant materials were obtained from the peanut germplasm collection at the USDA-ARS Plant Genetic Resources Conservation Unit (PGRCU) in Griffin, GA (Table 1). Most of the materials used in this study were plant germplasm accessions that have a plant introduction $(\mathrm{PI})$ number. The remaining samples were breeding lines that do not have an assigned $\mathrm{PI}$, but do have a unique identifier. Some of the materials included in this study have not been classified into subspecies or botanical varieties (Table 1). All taxonomic classifications were based on current GRIN classifications (http://www.arsgrin.gov/npgs/index.html).

Crosses between PI 652938 Florida-07 (Gorbet and Tillman, 2009) x PI 280688 A. hypogaea var hirsuta, PI 565455 Chico (Bailey and Hammons, 1975) x PI 653717 York, and PI 565455 Chico (Bailey and Hammons, 1975) x PI 578304 SunOleic 95R (Gorbet and Knauft, 1997) were performed to produce $F_{1}$ seeds to evaluate the ability to detect a heterozygous genotype with this assay. Seeds from each of these parents were obtained from the USDA-ARS Plant Genetic Resources Conservation Unit in Griffin, GA. Two seeds per entry were germinated by planting them in a metal food serving tray containing a 1:1 mixture of Metro-Mix 300 and perlite. Plants were watered daily using an automatic watering system and daylight was extended by turning the greenhouse lights on from $6 \mathrm{pm}$ to $11 \mathrm{pm}$. Greenhouse conditions were set to maintain temperatures between $21^{\circ} \mathrm{C}$ and $29.5^{\circ} \mathrm{C}$. Emasculation of anthers from flowers of the female parents started about 6 weeks after planting. Emasculations were preformed in the evening between 6:30-8:00 pm. Non-emasculated flowers were removed every morning. Flowers from the male parents were selected the next morning and placed in vials with water. Pollinations were performed between 8:30-10:00 am. Wire ties were used to mark the emasculated flowers and aid in identification of the desired pegs. $F_{1}$ seeds were harvested 130 days after the last pollination except for PI 565455 Chico (Bailey and Hammons, 1975) which was harvested 100 days after the last pollination.

\section{DNA extraction and real-time PCR assay}

DNA samples were extracted by following the directions from an Omega-BioTek E.Z.N.A Plant DNA kit (Norcross, GA.). Leaf tissue or seed slices from a single individual (75-150 mg) were used to extract 
DNA. Peanut tissue was placed in a $2 \mathrm{ml}$ micro-centrifuge tube along with two $3 \mathrm{~mm}$ tungsten carbide beads (Qiagen Valencia, CA.) and $600 \mu \mathrm{l}$ of $\mathrm{P} 1$ buffer from the Omega-BioTek kit. Tissue was pulverized by a Retsch Mixer Mill 301 (Leeds, UK) at $30 \mathrm{~Hz}$ for $3 \mathrm{~min}$. Extracts were quantified on a DyNA Quant 200 fluorometer from Hoefer Pharmacia Biotech (San Francisco, CA). In addition, all samples were loaded on a $1 \%$ agarose gel along with a Low DNA Mass ${ }^{\text {TM }}$ Ladder from Invitrogen (Carlsbad, CA) to evaluate quantity and quality of each extraction. Samples were subsequently diluted to $10 \mathrm{ng} / \mu \mathrm{l}$ for real-time PCR.

Genome specific SNPs identified from publically available sequence data derived from the wild progenitors of cultivated peanut for FAD2 were incorporated in the probe/primer design to select the A genome rather than the $B$ genome in this assay. Primers for this assay were synthesized by MWG Operon (Huntsville, AL). The sequence of the forward and reverse primers were 5' GCC GCC ACC ACT CCA ACA C 3' and 5' GTT ATA CCA TGA TAC CTT TGA TTT TGG TTT TG 3', respectively. Two $\operatorname{TaqMan}^{\circledR}$ probes with 5' reporter fluorophores, 3' minor groove binders (MGB) and 3' non-fluorescent quenchers (NFQ) were synthesized by Applied Biosystems (Foster City, CA). The sequences of the probes to discriminate the G448A mutation were 5' 6FAM CCT CGA CCG CAA CG MGBNFQ 3' and 5' VIC CCT CGA CCG CGA CG MGBNFQ 3', respectively. The VIC probe targeted the wild type allele $\left(O l_{1}\right)$ and the 6FAM probe targeted the mutant allele $\left(o l_{1}\right)$. The total product size was 83 base pairs. Optimum probe and primer concentrations for this assay were determined by testing a matrix of various primer/probe concentrations and choosing the condition which maximized the normalized reporter fluorescence $\left(\Delta R_{N}\right)$ and minimized the cycle threshold $\left(C_{T}\right)$. The total volume of the PCR reaction was $25 \mu \mathrm{l}$ and consisted of 1x TaqMan $^{\circledR}$ Genotyping Master Mix (Applied Biosystems), $0.16 \mu \mathrm{M}$ forward primer, $0.16 \mu \mathrm{M}$ reverse primer, $0.4 \mu \mathrm{M}$ VIC probe, $0.3 \mu \mathrm{M} 6 \mathrm{FAM}$ probe, and $0.4 \mathrm{ng} / \mu \mathrm{l}$ of DNA. (The TaqMan ${ }^{\circledR}$ Genotyping Master Mix includes AmpliTaq Gold ${ }^{\circledR}$ polymerase and ROX ${ }^{\mathrm{TM}}$ a passive internal reference to correct for signal variation between wells). All PCR reactions were performed in an $A B I$ StepOne ${ }^{\mathrm{TM}}$ real-time PCR machine (Applied Biosystems). The cycling conditions consisted of 1 cycle of $60^{\circ} \mathrm{C}$ for $30 \mathrm{sec}, 1 \mathrm{cycle}$ of $95^{\circ} \mathrm{C}$ for $10 \mathrm{~min}, 50$ cycles of $95^{\circ} \mathrm{C}$ for $15 \mathrm{sec}$ and $62^{\circ} \mathrm{C}$ for $1 \mathrm{~min}$, and a final cycle of $60^{\circ} \mathrm{C}$ for $30 \mathrm{sec}$. Each PCR run included non-template controls to ensure that reagents were free of contaminants. In addition, several positive controls were included in each run such as F435 to represent the homozygous recessive mutant allele, normal oleate lines to represent the homozygous dominant allele, and heterozygous $F_{1}$ progeny to signify both the mutant and wild type allele. StepOne version 2.0 (Applied Biosystems) was utilized to analyze and score genotypes using the default parameters.

\section{Gas chromatography}

Fatty acid composition was determined by GC on an Agilent 7890A (Agilent Technologies, Santa Clara, CA) gas chromatograph with a flame ionization detector (FID) as described previously (Barkley et al. 2010). Peaks were identified by comparison to a FAME standard mix RM-3 (Sigma-Aldrich, St Louis, MO). A total of eight fatty acids (palmitic C16:0, stearic C18:0, oleic C18:1, linoleic C18:2, arachidic C20:0, gadoleic C20:1, behenic C22:0, and lignoceric acid C24:0) were identified in each peanut sample.

\section{RESULTS AND DISCUSSION}

Peanut germplasm, high oleic cultivars, breeding lines, and accessions from the U.S. peanut mini core (Holbrook and Dong, 2005), with a wide range of oleic to linoleic ratios (O/L) were chosen to develop the FAD2A genotyping assay. All samples that were genotyped were also subjected to GC to ascertain the overall fatty acid composition (Figure 1a and Table 1). Normal peanut lines are generally characterized with oleic acid values ranging from $30-60 \%$ and linoleic acid greater than $10 \%$; however, high oleic peanut lines are characterized with an oleic acid value $>73 \%$, and $\mathrm{O} / \mathrm{L}$ ratio $>10$. In the samples evaluated, the predominant fatty acids detected were palmitic (C16:0), oleic (C18:1), and linoleic (C18:2). These three fatty acids comprised $86-91 \%$ of the total fatty acids detected in the extracted oil. This trend has been reported previously in peanuts (Norden et al. 1987; Moore and Knauft, 1989). The oleic acid content in the selected samples ranged from 34.99 to 81.33 and the O/L ratio ranged from 0.88 to 41.18 (Table 1 ). Generally, as the oleic acid increased in the samples the linoleic acid decreased. This general trend has also been demonstrated in previous studies (Andersen and Gorbet, 2002; Isleib et al. 2006). 
Table 1. Arachis hypogaea germplasm accessions and breeding lines evaluated for fatty acid composition and FAD2 genotyping

\begin{tabular}{|c|c|c|c|c|c|c|c|c|c|c|}
\hline PPI & Subspecies & $\begin{array}{c}\text { Botanical } \\
\text { Variety }\end{array}$ & $\begin{array}{l}\text { Cultivar / } \\
\text { Identifier }\end{array}$ & $\begin{array}{c}\text { Palmitic } \\
\text { C16:0 }\end{array}$ & $\begin{array}{c}\text { Stearic } \\
\text { C18:0 }\end{array}$ & $\begin{array}{l}\text { Oleic } \\
\text { C18:1 }\end{array}$ & $\begin{array}{c}\text { Linoleic } \\
\text { C18:2 }\end{array}$ & $\begin{array}{c}\text { O/L } \\
\text { Ratio }\end{array}$ & $\begin{array}{c}\text { FAD2A } \\
\text { Genotype }\end{array}$ & $\begin{array}{c}\text { FAD2B } \\
\text { Genotype }\end{array}$ \\
\hline 652938 & hypogaea & hypogaea & Florida- $07^{\mathrm{a}}$ & 6.70 & 2.50 & 81.33 & 2.70 & 30.16 & $\mathrm{Ol}_{1} \mathrm{Ol}_{1}$ & $\mathrm{Ol}_{2} \mathrm{Ol}_{2}$ \\
\hline 578304 & hypogaea & hypogaea & SunOleic $95 R^{b}$ & 5.79 & 2.55 & 80.56 & 2.96 & 27.22 & $\mathrm{Ol}_{1} \mathrm{Ol}_{1}$ & $\mathrm{Ol}_{2} \mathrm{Ol}_{2}$ \\
\hline 653717 & hypogaea & hypogaea & York & 5.89 & 3.13 & 80.30 & 1.95 & 41.18 & $\mathrm{Ol}_{1} \mathrm{Ol}_{1}$ & $\mathrm{Ol}_{2} \mathrm{Ol}_{2}$ \\
\hline $\mathrm{n} / \mathrm{a}$ & hypogaea & hypogaea & F435-2 & 6.82 & 2.94 & 78.84 & 3.03 & 25.99 & $\mathrm{O}_{1} \mathrm{Ol}_{1}$ & $\mathrm{Ol}_{2} \mathrm{Ol}_{2}$ \\
\hline $\mathrm{n} / \mathrm{a}$ & hypogaea & hypogaea & F435-1 & 6.86 & 2.54 & 78.53 & 3.40 & 23.12 & $\mathrm{Ol}_{1} \mathrm{Ol}_{1}$ & $\mathrm{Ol}_{2} \mathrm{Ol}_{2}$ \\
\hline 632380 & hypogaea & hypogaea & GEORGIA-02C ${ }^{c}$ & 6.12 & 1.45 & 74.80 & 6.12 & 12.22 & $\mathrm{Ol}_{1} \mathrm{Ol}_{1}$ & $\mathrm{Ol}_{2} \mathrm{Ol}_{2}$ \\
\hline 290594 & --- & --- & S1 63 & 7.99 & 2.42 & 60.11 & 21.94 & 2.74 & $\mathrm{Ol}_{1} \mathrm{Ol}_{1}$ & $\mathrm{Ol}_{2} \mathrm{Ol}_{2}$ \\
\hline 290620 & --- & --- & S1 89 & 8.02 & 5.85 & 59.85 & 19.42 & 3.08 & $\mathrm{Ol}_{1} \mathrm{Ol}_{1}$ & $\mathrm{Ol}_{2} \mathrm{Ol}_{2}$ \\
\hline $\mathrm{n} / \mathrm{a}$ & hypogaea & hypogaea & $1050-80^{f}$ & 8.93 & 3.59 & 58.68 & 20.53 & 2.86 & $\mathrm{Ol}_{1} \mathrm{Ol}_{1}$ & $\mathrm{Ol}_{2} \mathrm{Ol}_{2}$ \\
\hline $\mathrm{n} / \mathrm{a}$ & hypogaea & hypogaea & $1050-48^{f}$ & 9.39 & 3.04 & 57.64 & 22.36 & 2.58 & $\mathrm{Ol}_{1} \mathrm{Ol}_{1}$ & $\mathrm{Ol}_{2} \mathrm{Ol}_{2}$ \\
\hline 313129 & --- & --- & 0101 & 10.41 & 4.21 & 55.30 & 22.89 & 2.42 & $\mathrm{Ol}_{1} \mathrm{Ol}_{1}$ & $\mathrm{Ol}_{2} \mathrm{Ol}_{2}$ \\
\hline 290536 & --- & --- & S1 5 & 9.38 & 3.09 & 54.81 & 25.10 & 2.18 & $\mathrm{Ol}_{1} \mathrm{Ol}_{1}$ & $\mathrm{Ol}_{2} \mathrm{Ol}_{2}$ \\
\hline 502096 & fastigiata & peruviana & SPZ 491-1 & 11.17 & 2.42 & 51.62 & 27.82 & 1.86 & $\mathrm{Ol}_{1} \mathrm{Ol}_{1}$ & $\mathrm{Ol}_{2} \mathrm{Ol}_{2}$ \\
\hline 599595 & hypogaea & hypogaea & ViruGard & 8.42 & 4.12 & 51.47 & 28.32 & 1.82 & $\mathrm{Ol}_{1} \mathrm{Ol}_{1}$ & $\mathrm{Ol}_{2} \mathrm{Ol}_{2}$ \\
\hline 337406 & --- & --- & FAV 153 & 9.41 & 3.30 & 51.17 & 29.28 & 1.75 & $\mathrm{Ol}_{1} \mathrm{Ol}_{1}$ & $\mathrm{Ol}_{2} \mathrm{Ol}_{2}$ \\
\hline 496448 & --- & --- & Kongoussi III & 11.04 & 2.24 & 49.49 & 30.21 & 1.64 & $\mathrm{Ol}_{1} \mathrm{Ol}_{1}$ & $\mathrm{Ol}_{2} \mathrm{Ol}_{2}$ \\
\hline 158840 & hypogaea & hypogaea & -- & 9.74 & 2.74 & 48.92 & 30.90 & 1.58 & $\mathrm{Ol}_{1} \mathrm{Ol}_{1}$ & $\mathrm{Ol}_{2} \mathrm{Ol}_{2}$ \\
\hline 196644 & hypogaea & hypogaea & $47-67 A$ & 9.96 & 2.12 & 48.47 & 31.09 & 1.56 & $\mathrm{Ol}_{1} \mathrm{Ol}_{1}$ & $\mathrm{Ol}_{2} \mathrm{Ol}_{2}$ \\
\hline 319768 & --- & --- & $1066-20$ & 11.54 & 3.53 & 46.66 & 32.05 & 1.46 & $\mathrm{Ol}_{1} \mathrm{Ol}_{1}$ & $\mathrm{Ol}_{2} \mathrm{Ol}_{2}$ \\
\hline 651853 & hypogaea & hypogaea & Tifguard $^{d}$ & 9.58 & 1.94 & 46.30 & 33.92 & 1.37 & $\mathrm{Ol}_{1} \mathrm{Ol}_{1}$ & $\mathrm{Ol}_{2} \mathrm{Ol}_{2}$ \\
\hline 200441 & --- & --- & Taiwan Kotsubu & 11.44 & 4.25 & 43.20 & 33.38 & 1.29 & $\mathrm{Ol}_{1} \mathrm{Ol}_{1}$ & $\mathrm{Ol}_{2} \mathrm{Ol}_{2}$ \\
\hline 493729 & fastigiata & fastigiata & RCM 421 & 10.88 & 3.62 & 42.30 & 36.39 & 1.16 & $\mathrm{Ol}_{1} \mathrm{Ol}_{1}$ & $\mathrm{Ol}_{2} \mathrm{Ol}_{2}$ \\
\hline 339960 & --- & --- & -- & 12.01 & 3.92 & 41.96 & 35.78 & 1.17 & $\mathrm{Ol}_{1} \mathrm{Ol}_{1}$ & $\mathrm{Ol}_{2} \mathrm{Ol}_{2}$ \\
\hline 306358 & fastigiata & fastigiata & Valencia-R-28 & 12.22 & 3.94 & 40.66 & 34.75 & 1.17 & $\mathrm{Ol}_{1} \mathrm{Ol}_{1}$ & $\mathrm{Ol}_{2} \mathrm{Ol}_{2}$ \\
\hline 565455 & fastigiata & vulgaris & $\mathrm{Chico}^{\mathrm{e}}$ & 13.91 & 3.35 & 38.46 & 36.34 & 1.06 & $\mathrm{Ol}_{1} \mathrm{Ol}_{1}$ & $\mathrm{Ol}_{2} \mathrm{Ol}_{2}$ \\
\hline 576638 & hypogaea & hirsuta & SSD 6 & 17.17 & 2.61 & 36.11 & 37.89 & 0.95 & $\mathrm{Ol}_{1} \mathrm{Ol}_{1}$ & $\mathrm{Ol}_{2} \mathrm{Ol}_{2}$ \\
\hline 280688 & hypogaea & hirsuta & Guanajuato-2 & 17.39 & 2.38 & 36.06 & 37.96 & 0.95 & $\mathrm{Ol}_{1} \mathrm{Ol}_{1}$ & $\mathrm{Ol}_{2} \mathrm{Ol}_{2}$ \\
\hline 259639 & hypogaea & hypogaea & NO 15226 & 11.78 & 3.67 & 34.99 & 39.76 & 0.88 & $\mathrm{Ol}_{1} \mathrm{Ol}_{1}$ & $\mathrm{Ol}_{2} \mathrm{Ol}_{2}$ \\
\hline
\end{tabular}

: (Gorbet and Tillman, 2009)

(Gorbet and Knauft, 1997)

d: (Holbrook et al. 2008)

e: (Bailey and Hammons, 1975).

f: Breeding lines developed by USAID CRSP Bolivia, GA, FL, and USDA. 
The high oleic lines [Florida-07 (Gorbet and Tillman, 2009), York, SunOleic 95R (Gorbet and Knauft, 1997) and F435] included in this study are all derived from F435, and are well characterized, and thus, are known to include the G448A mutation in FAD2A and the 442insA in FAD2B (López et al. 2000; Yu et al. 2008; Chu et al. 2009; Barkley et al. 2010). All of the high oleic lines did produce the expected genotype $\left(\mathrm{Ol}_{1} \mathrm{Ol}_{1}\right)$ for $F A D 2 A$ with the real-time assay by displaying an increase in normalized fluorescence from the mutant targeting probe (6FAM) and had oleic acid (C18:1) values ranging from 74.80 to 81.33 (Table 1). On the other hand, normal peanuts lines had oleic acid values ranging from 34.99-60.11 and produced either the homozygous recessive $\left(\mathrm{ol}_{1} \mathrm{Ol}_{1}\right)$ or the homozygous dominant $\left(\mathrm{Ol}_{1} \mathrm{Ol}_{1}\right)$ genotype for FAD2A (Table 1 and Figure $1 \mathrm{~b}$ ). These significant differences in the oleic acid content between the high oleic and normal oleic samples with the $\mathrm{ol}_{1} \mathrm{Ol}_{1}$ genotype can be attributed to the influence of the $F A D 2 B$ genotype on the total oleic value (Table 1), since both mutations are required to produce a high oleic peanut.

In order to identify heterozygous $\left(\mathrm{Ol}_{1} \mathrm{Ol}_{1}\right)$ genotypes with the $F A D 2 A$ genotyping assay, deliberate crosses between high oleic lines $\left(\mathrm{ol}_{1} \mathrm{Ol}_{1} \mathrm{Ol}_{2} \mathrm{Ol}_{2}\right)$ and normal oleic lines $\left(\mathrm{Ol}_{1} \mathrm{Ol}_{1} \mathrm{Ol}_{2} \mathrm{Ol}_{2}\right)$ were carried out to produce $\mathrm{F}_{1}$ seeds. Crosses between PI 652938 Florida-07 (Gorbet and Tillman, 2009) x PI 280688 A. hypogaea var hirsuta, PI 565455 Chico (Bailey and Hammons, 1975) x PI 653717 York, and PI 565455 Chico (Bailey and Hammons, 1975) x PI 578304 SunOleic 95R (Gorbet and Knauft, 1997) were performed producing a total of $68 \mathrm{~F}_{1}$ seeds. Small slices of each seed $(\sim 75 \mathrm{mg})$ distal to the embryo were made in the seeds to extract DNA and subsequently determine the FAD2A genotype. Heterozygous hybrid lines were clearly detected with this assay. Hybrid lines displayed an increase in fluorescence for both the wild type targeting probe (VIC) and the mutant targeting probe (6FAM); though, the $\Delta R_{N}$ was significantly reduced comparatively to the homozygous genotypes (Figure 1b). Therefore, genotyping these putative $F_{1}$ seeds revealed that $45(66.2 \%)$ were hybrids; but, the remaining seeds were a product of self fertilization. Detecting the heterozygotes in either FAD2A and / or $F A D 2 B$ has been advantageous because $\mathrm{F}_{1}$ plants that are not derived from deliberate crossing can be eliminated at an early stage and all progenies that are still segregating in the $F_{2}$ or more advance generations can be rapidly identified and either eliminated or further used in breeding programs.

Genotype validation was assessed in part by comparing data collected here to previously published results. Five of the mutant $\mathrm{Ol}_{1} \mathrm{Ol}_{1} \mathrm{Ol}_{2} \mathrm{Ol}_{2}$ and wild type $\mathrm{Ol}_{1} \mathrm{Ol}_{1} \mathrm{Ol}_{2} \mathrm{Ol}_{2}$ genotypes from the U.S. peanut mini core (Holbrook and Dong, 2005) were selected in this study that were previously evaluated for the G448A mutation (Chu et al. 2007b). Genotyping results were identical with the real-time genotyping assay as the results obtained from the CAPS marker. A separate study also evaluated a few of the selected accessions (PI 280688, PI 331314, PI 274193, PI 578304, PI 632380, PI 652938, and PI 653717 ) used in this study to determine ol genotypes by utilizing an AS-PCR method (Chen et al. 2010). Overall, no differences were detected in the genotypes determined in different laboratories using potentially different seed sources and three different methods demonstrating that all of these methods are robust and congruent. However, one advantage of a real-time assay compared to the ASPCR method previously published is the ability to detect heterozygotes, since the AS-PCR method cannot clearly distinguish $\mathrm{Ol}_{1} \mathrm{Ol}_{1} \mathrm{Ol}_{2} \mathrm{Ol}_{2}$ from ol $\mathrm{Ol}_{1} \mathrm{Ol}_{2} \mathrm{Ol}_{2}$ (Chen et al. 2010). Another advantage is the speed of this assay since no post-PCR processing is required.

Generally, development of molecular markers linked to specific quality traits can be highly effective tools to help breeders generate improved cultivars and decrease the time and effort to characterize all of the generated progeny. There are however relatively few markers linked to important agronomic traits for peanuts but, research efforts in progress are focused on developing additional markers for marker assisted selection. As far as the authors are aware, there are developed markers and / or markers associated with Sclerotinia blight resistance (Chenault et al. 2009), root-knot nematode resistance (Chu et al. 2007a), rust resistance (Varma et al. 2005) and the oleic acid trait. More markers associated with disease resistance such as tomato spotted wilt virus (TSWV) resistance and other quality traits such as folic acid are needed to assist breeders in generating improved varieties. Even though the available markers are somewhat limited compared to other major crops, these available markers can be employed to evaluate progenies for the desired genotypes and phenotypes or to select appropriate parental genotypes prior to crossing. Currently, there are multiple methods [real-time PCR (Barkley et al. 2010), AS-PCR (Chen et al. 2010), and CAPS markers (Chu et al. 2007b; Chu et al. 2009) for breeders and researchers to employ to determine high oleic versus normal oleic peanuts by evaluating the key SNPs in FAD2 dependent on their technology / equipment available. Real-time PCR is currently the most rapid method to determine specific FAD2 genotypes among the currently available methods; however, it is more expensive in regards to consumables than the other developed FAD2 
genotyping methods. As far as the authors are aware, this is the first report of a real-time genotyping assay designed to detect SNPs in FAD2A.

\section{ACKNOWLEDGMENTS}

The authors gratefully thank Mr. Brandon Tonnis for collecting the fatty acid data used in this study. We also thank Drs. Kelly D. Chamberlin and Zhenbang Chen for their comments to improve the manuscript.

\section{DISCLAIMER}

Mention of trade names or commercial products in this article is solely for the purpose of providing specific information and does not imply recommendation or endorsement by the U.S. Department of Agriculture.

\section{REFERENCES}

ANDERSEN, P.C. and GORBET, D.W. (2002). Influence of year and planting date on fatty acid chemistry of high oleic acid and normal peanut genotypes. Journal of Agricultural and Food Chemistry, vol. 50, no. 5, p. 12981305. [CrossRef]

BAILEY, W.K. and HAMMONS, R.O. (1975). Registration of Chico peanut germplasm (Reg. No. GP 2). Crop Science, vol. 15, no. 1, p. 105. [CrossRef]

BARKLEY, N.A.; CHENAULT CHAMBERLIN, K.D.; WANG, M.L. and PITTMAN, R.N. (2010). Development of a real-time PCR genotyping assay to identify high oleic acid peanuts (Arachis hypogaea L.). Molecular Breeding, vol. 25, no. 3, p. 541-548. [CrossRef]

BRANCH, W.D. (2003). Registration of 'GEORGIA-02C' peanut. Crop Science, vol. 43, no. 5, p. 1883-1884. [CrossRef]

CHEN, Z.; WANG, M.L.; BARKLEY, N.A. and PITTMAN, R.N. (2010). A simple allele-specific PCR assay for detecting FAD2 alleles in both $\mathrm{A}$ and $\mathrm{B}$ genomes of the cultivated peanut for high-oleate trait selection. Plant Molecular Biology Reporter, vol. 28, no. 3, p. 542-548. [CrossRef]

CHENAULT CHAMBERLIN, K.D.; MAAS, A.L.; DAMICONE, J.P.; PAYTON, M.E. and MELOUK, H.A. (2009). Discovery and characterization of a molecular marker for Sclerotinia minor (Jagger) resistance in peanut. Euphytica, vol. 166, no. 3, p. 357-365. [CrossRef]

CHU, Y.; HOLBROOK, C.C.; TIMPER, P. and OZIAS-AKINS, P. (2007a). Development of a PCR-based molecular marker to select for nematode resistance in peanut. Crop Science, vol. 47, no. 2, p. 841-845. [CrossRef]

CHU, Y.; RAMOS, L.; HOLBROOK, C.C. and OZIAS-AKINS, P. (2007b). Frequency of a loss-of-function mutation in oleoyl-pc desaturase $(a h F A D 2 A)$ in the mini-core of the U.S. Peanut Germplasm Collection. Crop Science, vol. 47, no. 6, p. 2372-2378. [CrossRef]

CHU, Y.; HOLBROOK, C.C. and OZIAS-AKINS, P. (2009). Two alleles of ahFAD2B control the high oleic acid trait in cultivated peanut. Crop Science, vol. 49, no. 6, p. 2029-2036. [CrossRef]

DEAN, L.L.; HENDRIX, K.W.; HOLBROOK, C.C. and SANDERS, T.H. (2009). Content of some nutrients in the core of the core of the Peanut Germplasm Collection. Peanut Science, vol. 36, no. 2, p. 104-120. [CrossRef]

GORBET, D.W. and KNAUFT, D.A. (1997). Registration of 'SunOleic 95R' peanut. Crop Science, vol. 37, no. 4, p. 1392. [CrossRef]

GORBET, D.W. and TILLMAN, B.L. (2009). Registration of 'Florida-07' peanut. Journal of Plant Registration, vol. 3, no. 1, p. 14-18. [CrossRef]

HOLBROOK, C.C. and DONG, W. (2005). Development and evaluation of a mini core collection for the U.S. Peanut Germplasm Collection. Crop Science, vol. 45, no. 4, p. 1540-1544. [CrossRef]

HOLBROOK, C.C.; TIMPER, P.; CULBREATH, A.K. and KVIEN, C.K. (2008). Registration of 'Tifguard' peanut. Journal of Plant Registration, vol. 2, no. 2, p. 92-94. [CrossRef]

ISLEIB, T.G.; WILSON, R.F. and NOVITZKY, W.P. (2006). Partial dominance, pleiotropism, and epistasis in the inheritance of the high-oleate trait in peanut. Crop Science, vol. 46, no. 3, p. 1331-1335. [CrossRef]

JUNG, S.; SWIFT, D.; SENGOKU, E.; PATEL, M.; TEULE, F.; POWELL, G.; MOORE, K. and ABBOTT, A. (2000a). The high oleate trait in the cultivated peanut [Arachis hypogaea L.]. I. Isolation and characterization of two genes encoding microsomal oleoyl-PC desaturases. Molecular and General Genetics MGG, vol. 263, no. 5, p. 796-805. [CrossRef]

JUNG, S.; POWELL, G.; MOORE, K. and ABBOTT, A. (2000b). The high oleate trait in the cultivated peanut [Arachis hypogaea L.]. II. Molecular basis and genetics of the trait. Molecular and General Genetics MGG, vol. 263, no. 5, p. 806-811. [CrossRef]

LÓPEZ, Y.; NADAF, H.L.; SMITH, O.D.; CONNELL, J.P.; REDDY, A.S. and FRITZ, A.K. (2000). Isolation and characterization of the $\Delta^{12}$-fatty acid desaturase in peanut (Arachis hypogaea L.) and search for 
polymorphisms for the high oleate trait in Spanish market-type lines. TAG Theoretical and Applied Genetics, vol. 101, no. 7, p. 1131-1138. [CrossRef]

LÓPEZ, Y.; SMITH, O.D.; SENSEMAN, S.A. and ROONEY, W.L. (2001). Genetic factors influencing high oleic acid content in Spanish market-type peanut cultivars. Crop Science, vol. 41, no. 1, p. 51-56. [CrossRef]

LÓPEZ, Y.; NADAF, H.L.; SMITH, O.D.; SIMPSON, C.E. and FRITZ, A.K. (2002). Expressed variants $\Delta f{ }^{12}$-fatty acid desaturase for the high oleate trait in Spanish market-type peanut lines. Molecular Breeding, vol. 9, no. 3, p. 183-192. [CrossRef]

MOORE, K.M. and KNAUFT, D.A. (1989). The inheritance of high oleic acid in peanut. Journal of Heredity, vol. 80, no. 3, p. 252-253.

NORDEN, A.J.; GORBET, D.W.; KNAUFT, D.A. and YOUNG, C.T. (1987). Variability in oil quality among peanut genotypes in the Florida breeding program. Peanut Science, vol. 14, no. 1, p. 7-11. [CrossRef]

O'BYRNE, D.J.; KNAUFT, D.A. and SHIREMAN, R.B. (1997). Low fat-monounsaturated rich diets containing higholeic peanuts improve serum lipoprotein profiles. Lipids, vol. 32, no. 7, p. 687-695. [CrossRef]

RAY, T.K.; HOLLY, S.P.; KNAUFT, D.A.; ABBOTT, A.G. and POWELL, G.L. (1993). The primary defect in developing seed from the high oleate variety of peanut (Arachis hypogaea L.) is the absence of $\Delta^{12}$ desaturase activity. Plant Science, vol. 91, no. 1, p. 15-21. [CrossRef]

VARMA, T.S.N.; DWIVEDI, S.L.; PANDE, S. and GOWDA, M.V.C. (2005). SSR markers associated with resistance to rust (Puccinia arachidis Speg.) in groundnut (Arachis hypogaea L.). SABRAO Journal of Breeding and Genetics, vol. 37, no. 2, p. 107-119.

YU, S.; PAN, L.; YANG, Q.; MIN, P.; REN, Z. and ZHANG, H. (2008). Comparison of the $\Delta^{12}$ fatty acid desaturase gene between high-oleic and normal-oleic peanut genotypes. Journal of Genetics and Genomics, vol. 35, no. 11, p. 679-685. [CrossRef]

\section{How to cite this article:}

BARKLEY, N.A.; WANG, M.L. and PITTMAN, R.N. (2011). A real-time PCR genotyping assay to detect FAD2A SNPs in peanuts (Arachis hypogaea L.). Electronic Journal of Biotechnology, vol. 14, no. 1. http://dx.doi.org/10.2225/vol13-issue1-fulltext-12 